\title{
“Do Not Resuscitate Order" By Competent Adults: The Legal Position in the United States and Canada Perspectives
}

\author{
Fareed Mohd Hassan, Ph.D. \\ Faculty of Syariah and Law \\ Universiti Sains Islam Malaysia \\ Malaysia
}

\begin{abstract}
This paper analyses the position of the full age and mentally competent patient in exercising his or her right of autonomy to refuse treatment by giving an advance will or directive to the doctors in the lights of the United States and Canada laws. Even though there is a presumption that Cardiopulmonary Resuscitation; a treatment for cardiac arrest has to be given to the patient. The decision as to whether to withhold or withdraw such a treatment lies with health practitioners, and the court will only intervene on certain situations in the United States. However, in Canada, neither consent nor a court order in lieu is required for a medical doctor to issue a non-resuscitation direction where, in his or her judgment, the patient is in an irreversible vegetative state.
\end{abstract}

Keywords: Medical practice - Do Not Resuscitate Order - Advance Medical Directives - Withdrawal of LifeSustaining Treatment - Cardiopulmonary Resuscitation - Consent - Capacity - Medical judgment

\section{Introduction}

The Hippocratic Oath and other subsequent medical ethics have put forward paternalistic positions which emphasize the patient's well-being above anything else. In other words, the doctor's knows best position as to uphold the interest and life of the patient have been the significant principle in medical practice. However, since the advancement of the technology and the rapid development in medical practice, it receives many moral, legal inquiries and even critics.

The principle of doctor's knows best is no longer becomes absolute since public awareness has increased and the people are now more concern about their health. Patient's autonomy or the liberty of the patient, either in thoughts or actions has becomes an enemy to the doctrine of paternalism, the doctor's knows best. This may occur when, for instance, the patient is exercising his or her autonomy, declines treatment which about to be given to him or her by the doctor where the doctor feels, in accordance with the doctrine of paternalism that such treatment should be given. At this point of view, which principle should be dominant?

Generally speaking, where the patient is of full age and mentally competent to agree or refuse the treatment to be given, the patient's interest in exercising his or her autonomy to be respected is paramount. This paper will discuss the position of the full age and mentally competent patient in exercising his or her right of autonomy to refuse treatment by giving an advance will or directive to the doctors in the lights of the United States (U.S.) and Canada laws.

\section{What is "Do Not Resuscitate Order"?}

Do Not Resuscitate Order (DNRO) is also known as "Advance Medical Directives" or "Withdrawal of LifeSustaining Treatment". However, it is distinct to specific hospital events (Silfen, 1995). The DNRO is a physicians' order which communicate to nursing and hospital staff that resuscitative measures is not to be taken in the event a patient experiences a cardiopulmonary arrest(Murphy, 1988). If the patient were to experience a choking incident, stroke, or other a cute problem, resuscitative measures would be attempted.

In other words, a DNRO is an order written by physicians which directs that, in the event of a cardiac respiratory arrest, the patient is not be given Cardiopulmonary Resuscitation (CPR). The CPR is the treatment for cardiac arrest (Sorum, 1993). It refers to the various types of procedures available to physicians to "restore cardiac function or to support ventilation in the event of a cardiac or respiratory arrest". It is one of many lifesaving techniques which became widely available in the second half of the $20^{\text {th }}$ Century (McArdle, 2002). 
Examples of CPR include mouth-to-mouth rescue breathing, direct cardiac injection, intravenous medications, electrical defibrillation and open chest cardiac massage. ${ }^{1}$ In order for it to be effective, CPR must be started within minutes of the arrest. ${ }^{2}$ The DNRO is generally part of an advance directive by a patient who wishes to refuse CPR under certain circumstances: for instance, where the patient has a terminal condition and experiences cardiac arrest(Adelman, 2010). The DNRO is written with the permission of the patient or a minor patient's parent, after discussing it with appropriate medical specialists and after the hospital ethics committee reviews it (Gelfman \& Schwab, 2005).

Resuscitative measures should not be confused with measures designed to sustain life. The use of artificial means of nutrition and hydration, or measures to improve ventilation or cardiac function in the absence of a respiratory or cardiac arrest qualifies as life-sustaining measures not resuscitative measures(Emanuel, 1989).

The DNRO becomes involved in the court setting in two instances. First, health care providers will seek a declaratory judgment to approve a decision to issue a DNRO for a patient who is unable to make the decision himself (Vernaglia, 2009). The second situation occurs after the decision regarding the DNRO has been made, and the court must decide whether liability should attach to a provider for injuries caused by executing or not executing the order (Vernaglia, 2009). Rarely, a court order is required in some cases and the patient receives independent legal representation(Adelman, 2010 and Vernaglia, 2009).

\section{3. "Do Not Resuscitate Order" and Euthanasia}

The term 'euthanasia' is originated from Greek word euthanatos, which means good death or easy death (Pozgar, 2005). The Oxford English Dictionary defines euthanasia as the bringing about a merciful and painless death for persons suffering from an incurable and painful disease. Generally, euthanasia refers to the means of inducing or bringing about a gentle and easy death or death without suffering (Kassim, 2010). There are few types of euthanasia, but however, one of the types is closely related to the discussion of the DNRO, which is passive voluntary euthanasia. It is a combination of two types of euthanasia, passive and voluntary euthanasia.

Passive euthanasia is where available measure to prolong life is withheld or withdrawn from the patient. This includes not commencing treatment if patient's condition considered futile, disconnecting life support systems, discontinuing medical treatment necessary to sustain life or withholding supply of fluids and nutritional feeding (Kassim, 2010). In other words, passive voluntary euthanasia is where the physician discontinues medical treatment necessary to sustain or prolong the life of the patient with the consent by the patient himself. Voluntary euthanasia occurs when euthanasia is performed with the consent of the recipient, the patient (Kassim, 2010).

\section{Capacity for "Do Not Resuscitate Order"}

There is a presumption that CPR has to be given to the patient which is eminently sensible(Deciding to Forego Life-Sustaining Treatment: A Report on the Ethical, Medical, and Legal Issues in Treatment Decisions, 1983). First, a patient who suffers an arrest is, at least by virtue of the arrest, in no position to decide whether CPR should be administered. Second, if CPR is not administered, the patient almost certainly will die (Meisel, 1989). Thirdly, if permission to administer CPR is sought from the patient, as should ordinary be the case, the delay occasioned thereby could easily result either in death or severe brain damage. ${ }^{3}$ Consequently, at the time of an arrest, there is no time to seek a decision about the administration of CPR from either the patient or family members (Meisel, 1989).

\footnotetext{
${ }^{1}$ The Proposed Legislation and Report of the New York State Task Force on Life and the Law 3. 1988. New York: New York State Task Force on Life and Law. $2^{\text {nd }}$ edition. "Basic resuscitation involves the initiation and maintenance of respiration and heartbeat through simple techniques such as mouth-to-mouth resuscitation and external chest compression which can be administered without equipment by any person trained in CPR. Advanced resuscitation requires more sophisticated techniques and is performed by trained medical personnel".

${ }^{2}$ Ibid.

${ }^{3}$ In re Dinner stein Mass [1978] 380 N.E.2d 134, 6(Mass. App. Ct. 466), "these procedures, to be effective, must be initiated with a minimum of delay as celebral anoxia, due to a cutoff of oxygen to the brain, will normally produce irreversible brain damage within three to five minutes and total brain death within fifteen minutes.... 'The cells of the cerebral cortex, which control intellectual or cognitive functions, are destroyed in three to five minutes of anoxia; the cells of the midbrain and the brain stem, which control the body's vegetative functions, can survive for an additional few minutes, thus making possible a continued vegetative or comatose existence in some cases where circulation is restored after irreversible destruction of cells highest on the neuraxis"”. 
As far as the researcher is concern, the discussion will only be dealing with the issue of informed consent from the side of competent patient only. There is an issue on whether the informed consent of a competent patient is necessary to write an order to withhold CPR. As this issue has become larger, it has become a futile medical treatment. The question about the necessity to obtain informed consent to CPR would be a relatively simple matter if it were not for the existence of standing order for CPR to be administered to all patients suffering a cardiopulmonary arrest, which can only be avoided by writing a specific order not to resuscitate.

The conventional wisdom behind the issue is that the decision-making about the DNRO should begin on the same basis as decision-making about any other form of treatment. ${ }^{4}$ It is the responsibility of the physician to initiate a discussion about CPR if the patient's medical condition makes it reasonably foreseeable that the patient might suffer a cardiopulmonary arrest, and it is not the responsibility of the patient to initiate such a discussion. ${ }^{5}$

When the physician initiates a discussion about CPR, as about any other treatment, it should be aimed at ensuring that the patient understands what CPR is, the conditions under which it is used, its risks and benefits, and the consequences of not administering it when an arrest occurs (Meisel, 1989). Then the physician should determine whether the patient wishes for CPR to be administered or for a DNRO to be in written.

When the physician believes that CPR is futile in terms of saving the patient's life or returning the patient to a quality of life that the patient would find acceptable, the patient should be told this, and they should be advised that, should a cardiac arrest occurs, it is the physician's recommendations that CPR be withheld. However, CPR must not in fact be withheld unless there is consent to doing it so (Meisel, 1989).In other words, consent can render physical invasion lawful(Laurie \& Porter, 2016) since everyone has the right to self-determination with regard to his body. The common law has long recognized the principle that every person has the right to have his bodily integrity protected against invasion by others(Laurie \& Porter, 2016). ${ }^{6}$

The U.S.Supreme Court in $\mathrm{Cruzan}^{7}$ confirmed that a competent adult patient has a constitutional liberty interest in controlling the type of medical care he or she receives or rejects. In most situations involving competent adult patients, the patient is the primary player in the medical treatment decision. ${ }^{8}$ However, the range of players involved in the process grows rapidly in situations where the patient's mental capacity to make an informed treatment decision is uncertain or lacking, or the patient is comatose or in a persistent vegetative state (Schermer, 1990).A medical treatment decision process should include consultation with the patient, and, as necessary, the patient's family to determine the patient's wishes. The attending physician and any consulting physicians also should be involved (Schermer, 1990).

Furthermore, Lord Scarman, in Sidaway ${ }^{9}$ stated that this right to accept or refuse treatment "may be seen as a basic human right protected by the common law." Lord Temple man in the same case was of the opinion that the refusal may be for reasons that are rational or irrational or for no reason. The absolute and unconditional nature of the right of the competent patient was reiterated by Lord Mustill in the case of Airedale. ${ }^{10}$

\section{The Position of "Do Not Resuscitate Order" in the United States}

In the U.S., legislation regarding the treatment of incapable persons varies by state. Some states have enacted legislation which establishes surrogate decision-makers in the event a patient becomes incapacitated and has not previously appointed someone to make decisions on their behalf.

\footnotetext{
${ }^{4}$ Foody v Manchester Memorial Hospital [1984] 40 Conn. Supp. 127, 482 A.2d 713 (Super. Ct.) 719-720,“[t]he DNR order is based upon the philosophy that a person capable of giving informed consent has the right to make his own decision regarding medical care".

${ }^{5}$ Payne v Marion General Hospital [1990] 549 N.E.2d 1043 (Ind. App.)“[p] hysician must obtain informed consent to write DNR order for competent patient".

${ }^{6}$ This is also a human right issue. See YFv Turkey (2004) 39 EHRR 34 in which it was held that physical and psychological integrity of the person is protected by Article 8 of the European Convention on Human Rights (ECHR) and that compulsory medical intervention is an interference with this right irrespective of whether consent has been obtained. It falls, therefore, to the state to justify any such interference under Article 8(2) of the ECHR.

${ }^{7}$ Cruzan v Director, Missouri Department of Health [1990] 58 U.S.L.W. 4916.

${ }^{8}$ In re Austwick, No. 1-94-0885 [1995] (Ill. Ct. App.) (1995 Ill. App. LEXIS 696).

${ }^{9}$ Sidaway v Board of Governors of the Bethlem Royal Hospital and Maudsley Hospital [1985] 1 AC 871; [1985] 2 WLR 480.

${ }^{10}$ Airedale NHS Trust $v$ Bland [1993] 1 All E.R. 821 (HL).
} 
For example, in New York, Section 2994-d.1 of the Family Health Care Decisions Act sets forth that in order of priority, the persons who may act as a surrogate decision-maker for an incapable patient. It grants the surrogate the authority to make all health care decisions for the patient that the adult patient could make for him or herself, subject to certain limitations.

Another example of such legislation is the Illinois Health Care Surrogate Act. This legislation states that when a doctor determines a patient is incapacitated and no living will or power of attorney is in place, the doctor must try to determine whether the patient has any relatives or friends available to serve as a surrogate decision-maker. An order of priority is set out to determine who will serve as the decision-maker under Section 25 of the Act.

The leading case in the U.S. on end of life decisions and consent is Cruzan's case. In Cruzan, the family requested the termination of life-sustaining treatments to their relative who was in a persistent vegetative state. Hospital employees refused to terminate life support without the authorisation of the court. The U.S. Supreme Court affirmed the decision of the Supreme Court of Missouri, finding it was acceptable to require "clear and convincing evidence" of a patient's wishes for the removal of life support.

The court held that while individuals enjoyed the right to refuse medical treatment under the Due Process Clause, incompetent persons are not able to exercise such rights. Absent "clear and convincing" evidence that the patient desires treatment to be withdrawn; the court found the State of Missouri's actions designed to preserve human life to be constitutional. There was no guarantee that family members would always act in the best interests of incompetent patients, and because erroneous decisions to withdraw treatment were irreversible, the court upheld the state's heightened evidentiary requirements.

Another case as to illustrate the position of the DNRO in the U.S. is in the case of In re Dinnerstein ${ }^{11}$ where the Massachusetts Appeal Court determined that a decision to issue a DNRO does not require judicial approval. The court stated that the question of whether or not to issue a DNRO is not one for judicial decision, but one for the attending physician, in keeping with the highest traditions of his profession, and subject to court review only to the extent that it may be contended that he has failed to exercise "the degree of care and skill of the average qualified practitioner, taking into account the advances in the profession".

The Dinnerstein's case supports the contention that the decision as to whether to withhold or withdraw treatment lies with health practitioners, and the court should not play a role in such decisions. However, in cases after Dinnerstein, a different approach has been taken. For instance, in the case of In re Earl N. Spring, ${ }^{12}$ the Massachusetts Supreme Judicial Court overturned Dinner stein to the extent that it shifted the ultimate decisionmaking authority from the court to the physician and family members. The court stated that in Massachusetts there is a preference for judicial decision-making in cases involving difficult medical decision for incapacitated individuals.

The court further ruled that the following factors that should be considered in deciding the need for judicial approval of a desired medical treatment. First, the extent of impairment of the patient's mental faculties. Second, whether the patient is in the custody of a state institution. Third, the prognosis without the proposed treatment, Fourth, the prognosis with the proposed treatment, Fifth, the complexity, risk and novelty of the proposed treatment and its possible side effects. Sixth, the patient's level of understanding and probable reaction. Seventh, the urgency of decision. Eight, the consent of the patient, spouse or guardian, Ninth, the good faith of those who participate in the decision. Tenth, the clarity of professional opinion as to what is good medical practice. Eleventh, the interests of third persons, and twelfth, the administrative requirements of any institution involved. ${ }^{13}$

The Spring's case demonstrates that the U.S.' courts have acknowledged that they have a role to play in the decision to withhold or withdraw treatment. This role was demonstrated in the more recent case of Schindler vSchiavo. ${ }^{14}$ In Schiavo, a substitute decision-maker brought an application to the Sixth Circuit Court for Pinellas County, Florida to have life support withdrawn from a woman who was in a persistent vegetative state. The woman's parents opposed the application. The court ordered the removal of life support. The decision was followed by numerous motions and appeals to the Florida Second District Court of Appeal.

\footnotetext{
${ }^{11}[1978] 380$ N.E.2d 134, 6 Mass. App. Ct. 466 (CA).

${ }^{12}[1980] 405$ N.E.2d 115, 380 Mass. 629 (SC).

${ }^{13}$ In re Earl N. Spring [1980] 405 N.E.2d 115, 380 Mass. 629 (SC).

${ }^{14}$ In re Guardianship of Schiavo[2001] 780 So. 2d 176 (Fla. 2d DCA). 
The end result was that life support was withdrawn. This case illustrates a United States' court taking a very active role in an end of life decision, and not leaving the issue of final consent to the patient's doctors or substitute decision-maker.

The Spring's and Schiavo's cases illustrate that in the U.S., decisions as to whether to withdraw or withhold treatment are not necessarily left in the hands of health practitioners and the court does play an active role in determining these questions.

\section{The Position of "Do Not Resuscitate Order" in Canada}

As noted by M. Metivier J. in Children's Aid Society of Ottawa-Carleton v M.C. ${ }^{15}$ that there is very little case law in Canada on the meaning of the word treatment, and there is particularly little discussion of whether treatment can include a decision to cease treatment where a patient is terminally ill or has very little chance of survival. In the case of Child and Family Services,${ }^{16}$ it is one of the few cases that address this issue. In this case, the court found that the treatment of a patient, whether surgically, with drugs or by other intrusive means, involves a touching of the patient's person. Unless done with the consent of the patient, such a touching would ordinarily amount to an assault. ${ }^{17}$

The court further held that the word "treatment" is used only in appositive sense. There is no need for a consent from anyone for a doctor to refrain from intervening. There is no legal obligation on a medical doctor to take heroic measures to maintain the life of a patient in an irreversible vegetative state. The only fear a doctor needs to have in denying heroic measures to a patient is the fear of liability for negligence in circumstances where qualified practitioners generally would have thought intervention warranted. Neither a consent nor a court order in lieu is required for a medical doctor to issue an on-resuscitation direction where, in his or her judgment, the patient is in an irreversible vegetative state.

According to Child and Family Services' case, no consent is needed at common law for a doctor to withdraw or withhold treatment. In addition, Rotaru $v$ Vancouver General Hospital Intensive Care Unit ${ }^{18}$ provides further support for the proposition that a doctor does not need consent to withhold treatment. In this case, the physicians did not believe that dialysis treatment should be provided to a palliative patient. The court surveyed United Kingdom decisions which consistently held that as a doctor has no requirement to provide treatment, a court cannot order them to do so. Burnyeat J. agreed with the view that he "could not conceive of any circumstances in which it would be other than an abuse of power to require a medical practitioner to act contrary to the fundamental duty which that practitioner owed to his or her patient". On this basis, he refused to order the health practitioner to begin re-administering treatment that was provided to the patient in the past. ${ }^{19}$

In Children's Aid, M. Metivier J. found that the correct principle to apply in decisions of this nature is that "the decision to withdraw or withhold life-sustaining treatment is inherently a medical one, "within the sole purview of a patient's treating doctors". The court further held that consent is not needed for the doctors to make use of their professional judgment and discretion to cease treatment or give only palliative care". It is noted that in Children's Aid the application of the Health Care Consent Act ${ }^{20}$ was not considered.

The Child and Family Services, Rotaru and Children's Aid cases can be cited as authorities for the proposition that health practitioners do not need consent to withhold or withdraw treatment. This line of jurisprudence is significantly predicated on the idea that doctors do not have an obligation to treat a patient or a duty to provide treatment.

As we have seen, once a doctor-patient relationship is formed, the doctor's obligation is to treat the patient. However, this does not mean that the doctor has a duty to provide (and the patient a correlative right to receive) whatever treatment the patient may request. If a patient requests treatment which the doctor considers to be inappropriate and potentially harmful, the doctor's overriding duty to act in the patient's best interests dictates that the treatment be withheld.

${ }^{15}$ [2008] O.J. No. 3795, 301 D.L.R. (4th) 194 (SCJ).

${ }^{16}$ [1997] M.J. No. 568, 154 D.L.R. (4th) 409, 123 Man. R. (2d) 135 (CA).

${ }^{17}$ [10], [13]-[14] and [17]. See also Kivisalu v. Brown [2002] B.C.J. No. 3346; [2002] BCSC 1901; [200] 2 BC.C. LEXIS 5809 .

${ }^{18}$ [2008] B.C.J. No. 456, 2008 BCSC 318.

${ }^{19}$ See also In re D.F.[2004] O.C.C.B.D. No. 210 LO 04-1537 \& 1538.

${ }^{20}$ Health Care Consent Act (1996) S.O. 1996, Chapter 2, Schedule A.(Ontario). 
A doctor who accedes to a patient's request (or demand) and performs treatment which he or she knows, or ought to know, is contra-indicated and not in the patient's best interests, may be held liable for any injury which the patient suffers as a result of the treatment(Picard \& Robertson, 2007).

Likewise, there is no legal duty to perform treatment which the doctor reasonably believes to be medically futile, that is, treatment which offers no reasonable prospect of therapeutic benefit to the patient. However, many commentators have emphasised the potential dangers and problems underlying the concept of medical futility, particularly if it is interpreted broadly and used to justify the withholding of treatment for socio-economic and value-laden reasons. It is essential that strict limits be placed on this concept. Useful guidance is to be found in the report of the Special Senate Committee on Euthanasia and Assisted Suicide, which recommended that "futility" in this context should be construed very narrowly to mean "treatment that will, in the opinion of the health care team, be completely ineffective"(Picard \& Robertson, 2007).

The absence of a legal duty to perform and provide treatment supports the contention that at common-law, doctors do not need consent to withdraw or withhold treatment. However, in certain cases, Canadian courts have found that they have a role in adjudicating end of life decisions, and that such decisions are not entirely within the unilateral discretion of doctors.

In Sawatzky v Riverview Health Centre Inc., ${ }^{21}$ the Manitoba Court of Queen's Bench considered the application of a wife for an injunction preventing a hospital from imposing a "do not resuscitate order" on her husband. At the time, the husband had a tracheotomy and difficulty communicating. The do not resuscitate order was imposed without consultation with the wife. The court allowed the application, noting that, while at United Kingdom common law doctors do not require consent to implement such orders, these cases had not considered the issue in the context of the Charter. Beard J.found that there was a role for the courts in considering whether treatment should be withheld or withdrawn. ${ }^{22}$

While courts and judges do not have any expertise in making medical decisions, they do have expertise in resolving factual disputes and in making legal decisions. In the case of non-consensual medical decisions, be they decisions to provide, withdraw or refuse care or treatment, there is a role for the courts to play in making factual determinations and advising of the legality or illegality of disputed decisions before the patient is dead. The very suggestion that there is the option of a claim in negligence raises the fact that doctors can and, on occasion, do make mistakes.

Further, many of the decisions that they make are qualitative and there is much room for individual disagreement on the correctness of the decision. Such findings would surely guide the doctor as she or he makes these decisions. There is also a public interest aspect involved in some of these issues which needs to be recognised including, as was stated by Lord Keith in the Airedale ${ }^{23}$ case, the protection of the patients, the reassurance of the patients' families and the reassurance of the public. At the end of the day, it is the doctors who will have to make the medical decisions, but they will do so knowing the facts and the likely legal outcome of those decision. As is often said, justice must not only be done but be seen to be done. This is appropriate whether speaking of justice in the courtroom or justice in terms of medical care.

In Golubchuk v Salvation Army Grace General Hospital, ${ }^{24}$ the court considered the issue of the removal of life support. The substitute decision-maker had not consented to the health practitioner's proposal to remove a ventilator. P. Schulman J. allowed an injunction to prevent the doctor from removing the ventilator. Before determining that the injunction was appropriate, he rejected the hospital's argument that the court had no role in the matter as the health practitioner did not need consent to withdraw medical treatment. ${ }^{25}$ It should be noted that in Children's Aid Society, one of the grounds on which Golubchuk ${ }^{26}$ was distinguished was that the proposed withdrawal of treatment in Golubchuk ${ }^{27}$ involved physical intervention.

\footnotetext{
${ }^{21}$ [1998] M.J. No. 506, 167 D.L.R. (4th) 359 (QB).

${ }^{22}$ Ibid. See also Janzen v Janzen [2002] O.J. No. 450; [2002] O.T.C. 95 and Jin v Calgary Health Region [2007] A.J. No. 1100; 2007 ABQB 593; [2008] 2 W.W.R. 723.

${ }^{23}$ Airedale NHS Trust v Bland [1993] 1 All E.R. 821 (HL).

${ }^{24}$ [2008] M.J. No. 54, 2008 MBQB 49.

${ }^{25}$ Ibid. See also In re Findlay[2002] O.C.P.S.D. No. 42.

${ }^{26}$ Golubchuk v Salvation Army Grace General Hospital [2008] M.J. No. 54, 2008 MBQB 49.

${ }^{27}$ Ibid. 
Sweiss $v$ Alberta Health Services ${ }^{28}$ is another case that involved the decision to remove mechanical ventilation from a patient. The substitute decision-maker did not consent to the withdrawal of the machine, and the court granted an injunction preventing its withdrawal.

While the hospital argued that the application for an injunction should be dismissed because no consent is required for a physician to refrain from intervening, the court did not address this issue specifically in its reasons. However, the court clearly did not accept this argument as it granted the injunction. Sweiss ${ }^{29}$ servesas an interesting example of another case in which the court did not find that health practitioners do not require consent to withdraw treatment.

The Sawatzky, ${ }^{30}$ Golubchuk ${ }^{31}$ and Sweiss ${ }^{32}$ cases demonstrate that the common law position on whether consent is needed to withdraw or withhold treatment in Canada is not firmly decided. The inconsistencies in Canadian case law on the issue and the existence of jurisprudence supporting a duty to obtain consent in withdrawal of treatment circumstances lead to the conclusion that the law on whether consent is needed to withdraw or withhold treatment in Canada is not well-settled.

\section{Conclusion}

The advanced directives have its own advantages, inter alia, giving patients control of their destiny and therefore peace of mind, providing opportunity for dialogue, guiding health professionals in difficult cases and removing responsibility for difficult decisions from relatives. Above all these, it protects patient's autonomy. However, patients are not entirely autonomous in their decision-making since they have been influenced to some degree by the advice and information they receive and how the options are portrayed to them. Despites of all the above mentioned advantages of advanced directives or the DNRO, there are difficulties of the patients in making their views known unambiguously and the risks of pressure. In addition, advanced directives were seen as a covert measure for reducing treatment costs or limiting the amount of care given to the elderly and terminally ill.

\section{Bibliography}

\section{Books}

Kassim, P. N. (2010). Law and Ethics Relating to Medical Profession. Kuala Lumpur: International Law Book Services.

Laurie, G. T., \& Porter, G. (2016). Mason and McCall Smith's Law and Medical Ethics (10th ed.). Oxford: Oxford University Press.

Meisel, A. (1989). The Right To Die (2nd ed., Vol. 1). New York: Wiley Law Publications.

Gelfman, M. H. B., \& Schwab, N. (2005). Discrimination in School: S 504, ADA, and the Title IX. In N. Schwab \& M. H. B. Gelfman (Eds.), Legal Issues in School Health Services: A Resource for School Administrators, School Attorneys, School Nurses (pp. 335-358). New York: Authors Choice Press.

Picard, E. I., \& Robertson, G. B. (2007). Legal Liability of Doctors and Hospitals in Canada (4th ed.). Toronto: Thomson Carswell.

Pozgar, G. D. (2005). Legal and Ethical Issues for Health Professionals. Massachusetts: Jones and Bartlett Publishers.

\section{Articles}

Adelman, J. (2010). The School-Based Do-Not-Resuscitate-Order. DePaul Journal of Health Care Law, 13(2), 197-215.

Emanuel, L. L. (1989). Does the DNR Order Need Life-Sustaining Intervention? Time for Comprehensive Advance Directives. American Journal of Medicine, 86(1), 87-90.

McArdle, E. F. (2002). New York's Do-Not-Resuscitate Law: Groundbreaking Protection of Patient Autonomy or a Physician's Right to Make Medical Futility Determinations? DePaul Journal of Health Care Law, 6(1),

\footnotetext{
${ }^{28}$ [2009] A.J. No. 1303, 2009 ABQB 691.

${ }^{29}$ Ibid.

${ }^{30}$ Sawatzky v Riverview Health Centre Inc[1998] M.J. No. 506, 167 D.L.R. (4th) 359 (QB).

${ }^{31}$ Golubchuk v Salvation Army Grace General Hospital [2008] M.J. No. 54, 2008 MBQB 49.

${ }^{32}$ Sweiss v Alberta Health Services [2009] A.J. No. 1303, 2009 ABQB 691.
} 
$55-82$.

Murphy, D. J. (1988). Do-Not-Resuscitate Orders: Time for Reappraisal in Long-Term-Care Institutions. Journal of the American Medical Association, 260(14), 2098-2101.

Schermer, B. (1990). A Practical Guide for Hospital Counsel in Decisions to Withhold or Withdraw Medical Treatment. Journal of Health and Hospital Law, 23(9), 264-266.

Silfen, E. (1995). Theoretical and Generic Considerations for Hospital Life-Sustaining Treatment Policies. Journal of Health and Hospital Law, 28(1), 21-28.

Sorum, P. C. (1993). Limiting Cardiopulmonary Resuscitation. Albany Law Review, 57, 617-646.

\section{Cases}

Airedale NHS Trust v Bland [1993] 1 All E.R. 821 (HL).

Children's Aid Society of Ottawa-Carleton v M.C., [2008] O.J. No. 3795, 301 D.L.R. (4th) 194 (SCJ).

Child and Family Services of Manitoba v L. (R.) [1997] M.J. No. 568, 154 D.L.R. (4th) 409, 123 Man. R. (2d) 135 (CA).

Cruzan v Director, Missouri Department of Health. (1990) 58 U.S.L.W. 4916.

Foody v Manchester Memorial Hospital 482 A.2d 713, 719-720 Conn. Super. Ct. 1984.

Golubchuk v Salvation Army Grace General Hospital [2008] M.J. No. 54, 2008 MBQB 49.

In re Austwick, No. 1-94-0885[1995](Ill. Ct. App.) (1995 Ill. App. LEXIS 696).

In re D.F.[2004] O.C.C.B.D. No. 210 LO 04-1537 \& 1538.

In re Dinnerstein Mass [1978] 380 N.E.2d 134, 6 (Mass. App. Ct. 466).

In re Earl N. Spring [1980] 405 N.E.2d 115, 380 Mass. 629 (SC).

In re Findlay[2002] O.C.P.S.D. No. 42.

In re Guardianship of Schiavo 780 So. 2d 176 (Fla. 2d DCA 2001).

Janzen v Janzen [2002] O.J. No. 450; [2002] O.T.C. 95.

Jin v Calgary Health Region [2007] A.J. No. 1100; 2007 ABQB 593; [2008] 2 W.W.R. 723.

Kivisalu v Brown [2002] B.C.J. No. 3346; 2002 BCSC 1901; 2002 BC.C. LEXIS 5809.

Payne v Marion General Hospital [1990] 549 N.E.2d 1043 (Ind. App.).

Sawatzky v Riverview Health Centre Inc[1998] M.J. No. 506, 167 D.L.R. (4th) 359 (QB).

Re T (adult: refusal of medical treatment)[1992] 4 All ER 649.

Sidaway v Board of Governors of the Bethlem Royal Hospital and Maudsley Hospital [1985] 1 AC 871; [1985] 2 LR 480.

Sweiss v Alberta Health Services [2009] A.J. No. 1303, 2009 ABQB 691.YF v Turkey (2004) 39 EHRR 34.

\section{Published Public Documents}

New York Family Health Care Decisions Act

Health Care Consent Act, 1996, S.O. 1996, c. 2, Sch. A.

Illinois Health Care Surrogate Act755 ILCS 40

President's Commission for the And, Ethical Problems in Medicine Research, Biomedical and Behavioral Study,Deciding to Forego Life-Sustaining Treatment: A Report on the Ethical, Medical, and Legal Issues in Treatment Decisions. (1983). Washington.

Vernaglia, Lawrence W. (2009). Propriety of, and liability related to, issuance orenforcement of Do Not Resuscitate (DNR) Orders. 46 A.L.R.5th 793 